EFFECT OF SALT LOADING ON CARDIOVASCULAR RESPONSE

79 TO MENTAL STRESS IN ADOLFSCENTS. Falkner, B., Onest1, G. Gould, A., Hayes, P. Hahnemann Medical College, Ph1la., Pa., U.S.A.

The effects of salt loading on the cardlovascular response to mental stress was compared between 8 adolescents with high genetic risk (Cenetic group) for essentlal hypertension (hypertensive parents) and 8 adolescents with low risk (Control group) (normotensive parent). Systollc (S), Diastollc (D) pressure and heart rate (IIR) were monftored (Arteriosonde) at 1 minute intervals during difficult mental arithmetic. Plasma catecholamines (CA) were determined before and after stress. Subjects then consumed $10 \mathrm{gm} /$ day $\mathrm{Na} \mathrm{Cl}$ in excess of usual diet for 14 days. Mental stress and $\mathrm{CA}$ were then repeated. Measurement of urine Ma conflrmed high salt intake. A greater cardiovascular response (greater increase in $S, D$, and $H R$ ) was seen in Genetic group compared to Control ( $p<.01$ ). Salt loading increased $\mathrm{BP}$, augmented the high $D$ resnonses and supnressed $C A$ in the Cenetic group. Salt loading produced no change in BP or CA in Controls. Concl: Cenetic adolescents have a higher cardiovascular response to mental stress. Some senetic adolescents are salt sensitive. Control adolescents are salt resistant.
CHANGES IN RENAL FUNCTION AND MORPHOLOGY IN STREPTOZO-

80 TOCIN (STZ) AND PANCREATECTOMIZED (PX) RHESUS MONKEYS (RM). John EG, Manaligod J, Miller J, Jonasson 0 , Univ. of I11. and Cook County Hosp. Dept. of Pedtatrics Anatomy and Surg. Chicago. U.S.A.

This study was undertaken to examine the degree of renal (R) functional and structural (S) involvement in STZ-Insulin (I) dependent (STZI, for 3-8 years; I requirement 2-7 U/day) or STZ carbohydrate disturbed ( $\mathrm{CHO}$, for 3-9 years) or $\mathrm{Px}$ (for 2-4 years; $I, 2-7 \mathrm{U} /$ day) model of diabetes (D) In RM. Glomerular filtration rate (GFR) renal plasma flow (RPF) urinary protein (UP) and kidney biopsy (BX) were done. Bx was evaluated by 11 ght microscopy (LM). In STZI and PX blood sugar ranged between $150-400 \mathrm{mg} \%$.

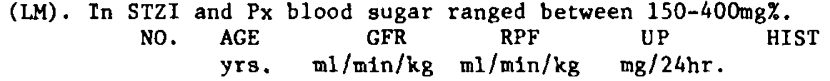

$\begin{array}{lrrllll} & & \text { yrs. } & \mathrm{ml} / \mathrm{min} / \mathrm{kg} & \mathrm{ml} / \mathrm{min} / \mathrm{kg} & \mathrm{mg} / 24 \mathrm{hr} . & \\ \text { CONTROL(C) } 29 & 6-17 & 2.21+.04 & 5.02 \pm .24 & 30+14 & 0 \\ \text { CHO } & 7 & 13-17 & 1.69 \pm .19 \star & 3.95 \pm .52 & 113+57 * & 0 \\ \text { STZ-I } & 7 & 10-16 & 2.09 \pm .28 & 4.47 \pm .50 & 118+50 * & + \\ \text { PX } & 8 & 6-13 & 2.67 \pm .14 & 5.94 \pm .52 & 70+10 \star & +\end{array}$
$\begin{array}{ccccc}8 & 6-13 & 2.67 \pm .14 & 5.94 \pm .52 & 70+10 *\end{array}$ compared to $C$. GFR and RPF was high in Px compared to $C$ but not
significant. There was significant proteinuria (P) in CHO, STZI, and $\mathrm{PX}$. In 4/5 STZT and $3 / 5 \mathrm{PX}$ LM change consisted of basement membrane thickening and increase in mesangial matrix. LM change and $P$ In STZI and PX suggest $D$ nephropathy. This study also suggests that structural changes (SC) can precede $R$ dysfunction $e . g$. STZ and Px or vice-versa e.g. CHO. Early I therapy did not prevent SC in STZ or PX, most probabiy due to inadequate D control. $\star P<.05$.

\section{RENAL OSTEODYSTROPHY}

PAEDIATRIC RENAL OSTEODYSTROPHY: Hoㅡ므으,

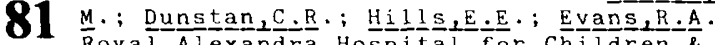
Concord Hospital, Sydney, N.S.W. Australia. To determine the prevalence of renal osteodystrophy 47 children, aged $1-17$ yrs, with glomerular filtration rates $(G F R)<80 \mathrm{ml} / \mathrm{min} / 1.73 \mathrm{~m}^{2}$ underwent bone biopsies after double tetracycline labelling. Histological parameters in undecalcified sections were measured by a digitizer interfaced to a computer. Control data was from 9 children, aged 1-14 yrs. Hyperparathyroid bone disease(HPD) \& osteomalacia(OM) were diagnosed by increases in resorbing surface \& decreases in mineralization front respectively. In group 1 (GFR) $30 \mathrm{ml} / \mathrm{min} / 1.73 \mathrm{~m}^{2}: 16$ children), 4 children had increased osteoid surfaces. Changes in other histological parameters were not seen. In group 2 (GFR 20-29ml) $\mathrm{min} / 1.73 \mathrm{~m}^{2}$ ), 3 children had HPD. In group 3 (GFR< $\left.20 \mathrm{~m} 1 / \mathrm{min} / 1.73 \mathrm{~m}^{2}: 23 \mathrm{children}\right), \mathrm{l} 2 \mathrm{children}$ had HPD, 2 $O M$ \& 9 mixed disease(MD). X-rays \& alkaline phosphatase levels were normal in 10 children with histological changes (HPD 6, OM 1, MD 3). Parathyroid hormone levels were elevated in 22 children with \& 10 without histological changes. Serum calcium phosphorus \& bicarbonate did not correlate with any histological parameters. Thus renal bone disease was only seen in children with GFRs $<30 \mathrm{ml} / \mathrm{min} / 1.73 \mathrm{~m}^{2}$ \& was only reliably ciagnosed by bone tiopsy.
SERUM 1,25 -DIHYDROXYVITAMIN D $\left(1,25-(\mathrm{OH}){ }_{2} \mathrm{D}\right)$ LEVELS IN

82 CHILDHOOD RENAL DISEASE. Chesney, R.W., Hamstra, A.J and Deluca, H.F. The University of Wisconsin, Madisor Wisconsin, USA.

The renal $I \alpha$-hydroxylation of vitamin D yields $1,25-(\mathrm{OH}), D$, the hormonally active form of the vitamin. Serum levels are markediy reduced in uremic children with demineralization and osteodystrophy (Chesney et al Am J Dis Child 134:135,1980). Using a precise assay, we have measured serum $1,25-(\mathrm{OH}), D$ in 27 children with various glomemar $(n=15)$ and tubular $(n=12)$ diseases, not treated with steroids which reduce $1,25-(\mathrm{OH}){ }_{2} D$ (Chesney et al Lancet II 1123,1978 ). Serum was obtained in the fasting state on usual diet. Levels were compared to age-matched controls $(2-16$ yr) and in terms of creatinine clearance using the Schwartz formula based on height and serum creatinine.

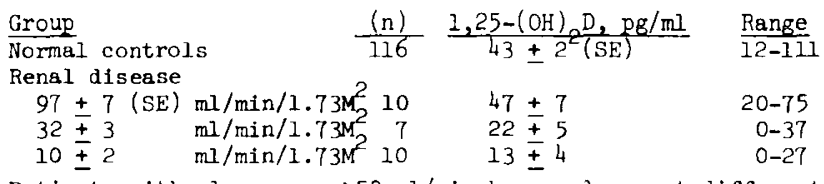

Patients with clearances $>50 \mathrm{ml} / \mathrm{min}$ have values not different from normal; from $25-50 \mathrm{ml} / \mathrm{min}$ (mean 32) have significant reduction compared to controls $(p<.01$ ) and below $25 \mathrm{ml} / \mathrm{min}$ have greatly reduced values $(p<.001)$. This data suggests that defective production of $1,25-(\mathrm{OH})_{2} \mathrm{D}_{3}$ begins at $\approx 35 \mathrm{ml} / \mathrm{min} / 1.73 \mathrm{M}^{2}$ and may be important in the high Incidence of osteodystrophy found in children.

83 RENAL OSTEODYSTROPHY IN CHILDREN:THERAPY WITH VITAMIN D OR 1,25-DIHYDROXY-CHOLECALCIFEROL $(1,25$-DHCC) Bulla,M., Delling, G. of fermann, G., ziegler, R. Kinderklinik Universităt Köln; Institut für Pathologie der Universităt Hamburg;Med.Klinik + Poliklinik Fu Berlin;Abt.f.Endokrinologie,Zentrum Innere Medizin u.Kinderheilkunde, Universităt Ulm, FRG

Growth arrest and renal osteodystrophy is a major problem in renal insufficiency of children. The present report describes our experiences in managing renal osteodystrophy in 16 children on maintained hemodialysis treatment by using vitamin $D_{3}$ for 12 to 18 months and in 14 dialyzed children by using 1,25-DHCC for 12months In treatment with vitamin $D_{3}$ plasma-Ca,alkaline phosphatase and iPTH normalized nearly.Radiographic abnormalities improved.Bone biopsies showed improvement in signs of secondary hyperparathyreodism and ostitis fibrosa, whereas osteomalacia remained unchanged and osteoblast population showed a small reduction. No real increment in body growth was seen. In treatment with 1,25-DHCC alkaline phosphatase and IPTH normalized completely.Radiographic examinations revealed marked improvement. Histological signs of fibroosteoclasia and resorptive defects disappeared but there was no recovery of osteomalacia.A reduction of osteoblast population and of bone transformation was obvious. 1,25-DHCC, also, failed to normalize growth in uremic children.Summarizing, neither vitamin $D_{3}$ nor 1,25-DHCC can guarantee complete recovery of renal osteodystrophy and growth arrest in uremic children.

EFFECT OF VITAMIN D, AND $1,25(\mathrm{OH})_{2} D_{3}$ ON

84 GROWTH IN EXPERIMENTAL UREMIA (EU) Gilli, G., Ritz,E., Mehls,o., v.d. Linden, A. University Children's Hospital, Heidelberg, F.R.G. Growth retardation is a major unsolved problem in children with chronic renal fallure. A stimulatory effect of $D_{3}$ on growth rate in EU has been demonstrated (Mehls et al., Am.J.clin.Nutr.,1978), but clinical results are conflicting. Chesney et al. (New Eng.J.Med., 1978) reported increased growth velocity in uremic children treated by $1,25(\mathrm{OH})_{2} D_{3}$ who had failed to respond to high dosage $D_{3}$. The present study was designed to compare the efficacy of $D_{3}$ and $1,25(\mathrm{OH})_{2} \mathrm{D}_{3}$ (3point dose response curve) on growth in rats with EU. Methods: $90 \mathrm{~g}$ male sprague-Dawley rats with stable uremia (2-stage subtotal nephrectomy) of 3 weeks' duration ( $C_{C y} 188$ of normal). All animals fed ad lib. Five groups: ${ }^{C} \mathrm{NX}$ solvent; II and III $N X+D,(0.5$ and 1.0 $\mu \mathrm{g} / 70 \mathrm{~g} / \mathrm{day}) ; \mathrm{IV}$ and $\mathrm{V}: \mathrm{NX}+1,25(\mathrm{OH})_{2} \mathrm{D}_{3}(0.625$ and $1.25 \mathrm{ng} / 70 \mathrm{~g} /$ day). Results: Serum Ca increased ( $\mathrm{p}<0.01$ ) to the same extent in III and $v$. In comparison to not treated animals (I), growth rate was significantly better in III and $V$ for both weight (III and V:p<0.01) and length (III and $v$ : p (0.05), but there was no difference between III and $V$. Conclusion: The present study cannot confirm that $1,25(\mathrm{OH})_{2} \mathrm{D}_{3}$ has a more beneficial effect on growth than vitamin $D$, . 